The third hemoprotein isolated in the hydroxylapatite chromatography (cytochrome $b-562$ ) could better be purified from the soluble fraction obtained from the sonicate of intact cells by DEAE-cellulose column chromatography followed by ammonium sulfate fractionation and hydroxylapatite column chromatography. As shown in Fig. 2, the pigment thus purified showed absorption bands at $562 \mathrm{~m} \mu(\alpha)$, $532 \mathrm{~m} \mu(\beta)$ and $427 \mathrm{~m} \mu$ (Soret) in the reduced form and at $420 \mathrm{~m} \mu$ (Soret) in the oxidized form. These spectra resembled those reported for "cytochrome $b$ " of Bacterium anitratum ${ }^{11}$. The prosthetic group of this cytochrome was identified as protoheme from its pyridine hemochromogen spectrum. This pigment was definitely different from cytochrome $b_{1}$ (ref. 7) not only in its spectral properties but also in its unusual nonautoxidizability. Cyanide and $\mathrm{CO}$ again showed no affinity to this cytochrome.

The three soluble cytochromes described in this paper seemed to be present also in E. coli B, E. coli var communior and Serratia marcescens grown under similar conditions.
Institute for Protein Research, $\quad$ TAKESH FuJITA Osaka University, $\quad$ Ryo SATo Kita-Ku, Osaka (Japan)

1 A. Tissières, in J. E. Falk, R. Lemberg and R. K. Morton, Haematin Enzymes, Pergamon Press, Oxford, 196I, p. 218.

2 B. Chance, J. Biol. Chem., 202 (1953) 383.

${ }^{3}$ L. N. Castor and B. Chance, J. Biol. Chem., 234 (1959) I 587.

${ }^{4}$ C. T. Gray, J. W. T. Wimpenny, D. E. Hughes and M. Ranlett, Biochim. Biophys. Acta, 67 (1963) I57.

5 J. W. T. Wimpenny, M. Ranlett and C. T. Gray, Biochim. Biophys. Acta, 73 (1963) i 70.

6 E. Itagaki, T. Fujita And R. Sato, J. Biochem. (Tokyo), 52 (I962) I 3 I.

7 T. Fujita, E. Itagaki and R. Sato, J. Biochem. (Tokyo), 53 (1963) 282.

${ }^{8}$ D. L. Drabkin, J. Biol. Chem., 146 (1942) 605.

9 H. Nishibayashi, T. Omura and R. Sato, Biochim. Biophys. Acta, 67 (1963) 520.

${ }^{10}$ M. Richmond and N. O. KjeldgaArd, Acta Chem. Scand., 15 (I96r) 226.

${ }^{11}$ J. G. Hauge, Arch. Biochem. Biophys., 94 (196I) 308.

Received September I6th, I963

Biochim. Biophys. Acta, 77 (1963) 690-693

PN 10077

\title{
Citryl-CoA and the citrate condensing enzyme
}

Previous work from this laboratory ${ }^{1,2}$ has shown that a preparation of synthetic citryl-CoA which was cleaved by the citrate cleavage enzyme to acetyl-CoA and oxaloacetate, inhibited the citrate condensing enzyme. It is the purpose of this paper to extend our earlier observations and present evidence which indicates that the inhibition by citryl-CoA is competitive for both acetyl-CoA and oxaloacetate. It is further shown that the slow cleavage of citryl-CoA catalyzed by condensing enzyme, which was first reported by EGGERER AND REMBERGER ${ }^{3}$, occurs at the same site as acetyl-CoA and oxaloacetate condensation.

Abbreviation: DTNB, 5, $5^{\prime}$-dithio-bis-2-nitrobenzoic acid. 
ELLMAN $^{4}$ has reported that when DTNB reacts with free sulfhydryl groups 2-nitrobenzoate mercaptide is formed which has a strong absorption maximum at $4 \mathrm{I} 2 \mathrm{~m} \mu$. If DTNB is added to a reaction mixture containing condensing enzyme and its substrates, the rate of appearance of CoASH can be assayed spectrophotometrically by observing the rate of change of absorption at $4 \mathrm{I} 2 \mathrm{~m} \mu^{5,6}$.

Since the conversion of DTNB to the mercaptide has an isosbestic point at $355 \mathrm{~m} \mu$, it is possible to follow the utilization of oxaloacetate generated from malate, $\mathrm{NAD}^{+}$and malate dehydrogenase (EC I.I.I.37) by the appearance of NADH at $355 \mathrm{~m} \mu$ and simultaneously the appearance of $\mathrm{CoASH}$ by its reaction with DTNB at $4 \mathrm{I} 2 \mathrm{~m} \mu$. Table I shows the change in absorbancy occurring simultaneously at

\section{TABLE I}

INHIBITION OF CONDENSING ENZYME BY CITRYL-COA

Cuvettes contained Ioo $\mu$ moles Tris- $\mathrm{HCl}$ (pH 8.I), Ioo $\mu$ moles potassium malate, $0.4 \mu$ mole $\mathrm{NAD}^{+}, 0.1$ unit malate dehydrogenase, o. $2 \mu$ mole acetyl-CoA, $0.03 \mu$ mole DTNB, and o.o I I unit condensing enzyme in a total volume of $\mathrm{I} \mathrm{ml}$. Citryl-CoA, prepared by reacting the mixed anhydride of citric acid with $\mathrm{CoASH}^{2}$, was purified using the CoA chromatography method of Moffatt and Khorana ${ }^{8}$. Citryl-CoA was assayed using the citrate cleavage enzyme ${ }^{7,9}$.

\begin{tabular}{lcc}
\hline \multirow{2}{*}{ Contents of curette } & \multicolumn{2}{c}{ AA per min } \\
\cline { 2 - 3 } & $412 \mathrm{mu}$ & $355 \mathrm{~m} \iota$ \\
\hline Complete system & 0.155 & 0.034 \\
+6 m $\mu$ moles citryl-CoA & 0.015 & 0.000 \\
\hline
\end{tabular}

$412 \mathrm{~m} \mu$ and $355 \mathrm{~m} \mu$ in a citrate condensing enzyme assay system. Upon the addition of citryl-CoA an inhibition of oxaloacetate utilization and CoASH liberation occurs. These results are in agreement with our early work ${ }^{\mathbf{1}, \mathbf{2}}$ and with the data reported by EgGerer AND REMBERGER ${ }^{3}$. The data shown in Table II confirm the observations of these authors that in the presence of large quantities of condensing enzyme a hydrolysis of citryl-CoA occurs. The rate of this reaction is about one-tenth the rate of the citrate condensing reaction.

As pointed out by EGGERER AND REMBERGER ${ }^{3}$ one would expect the $v_{\text {max }}$ for hydrolysis of citryl-CoA to be at least as high as that for the condensing reaction. Since the chemical synthesis of citryl-CoA leads to the formation of diastereomers

\section{TABLE II}

HYDROLYSIS OF CITRYL-COA BY CONDENSING ENZYME

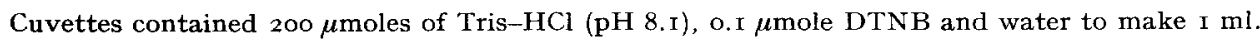

\begin{tabular}{ccc}
\hline $\begin{array}{c}\text { Enzyme } \\
\text { (units) }\end{array}$ & $\begin{array}{c}\text { Citryl-CoA } \\
\text { (mumoles) }\end{array}$ & $\begin{array}{c}\text { AA per min } \\
(412 \mathrm{m \mu})\end{array}$ \\
\hline & $\mathrm{I} 2$ & 0.560 \\
0.35 & 3.0 & 0.095 \\
0.35 & 1.2 & 0.030 \\
0.35 & 3.0 & 0.033 \\
0.035 & 2.4 & 0.028 \\
0.035 & 1.8 & 0.017 \\
0.035 & & \\
\hline
\end{tabular}


and since the condensing enzyme is highly stereospecific, these results could be explained if the unnatural isomer is an inhibitor for the reaction.

The results in Table III show that inhibition of condensing enzyme reaction by synthetic citryl-CoA can be overcome by increasing either the acetyl-CoA or oxaloacetate concentration. The synthetic citryl-CoA preparation contains, therefore, not only a substrate but a potent competitive inhibitor for both substrates.

TABLE III

EFFECT OF ACETYL-COA AND OXALOACETATE ON CITRYL-COA INHIBITION

Cuvettes contained in addition to the components listed $200 \mu$ moles Tris- $\mathrm{HCl}(\mathrm{pH}$ 8. I), o.I $\mu$ mole DTNB and 0.007 unit condensing enzyme in a total volume of $1 \mathrm{ml}$.

\begin{tabular}{|c|c|c|c|c|}
\hline $\begin{array}{c}\text { Acetyl-CoA } \\
(\mu m o l e s)\end{array}$ & $\begin{array}{c}\text { Oxaloacetate } \\
(\mu \text { moles })\end{array}$ & $\begin{array}{l}\text { Citryl-CoA } \\
\text { (mpmoles) }\end{array}$ & 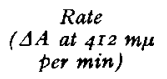 & $\begin{array}{c}\text { Inhibition } \\
(\%)\end{array}$ \\
\hline 0.06 & O.I & 0.0 & o.130 & - \\
\hline 0.06 & o.I & 6.0 & 0.037 & $7^{2}$ \\
\hline 0.06 & I.O & 0.0 & o.I 75 & 一 \\
\hline 0.06 & 1.0 & 6.0 & 0.053 & 70 \\
\hline 0.3 & $0 . I$ & 0.0 & 0.280 & - \\
\hline 0.3 & O.I & 6.0 & o.I 45 & $4^{8}$ \\
\hline 0.3 & 1.0 & 0.0 & $0.34^{\circ}$ & - \\
\hline 0.3 & 1.0 & 6.0 & 0.335 & I. 5 \\
\hline
\end{tabular}

By allowing large amounts of citrate condensing enzyme to cleave consecutive aliquots of citryl-CoA the natural diastereomer is hydrolyzed and one can accumulate the "unnatural" isomer. The results of such an experiment shown in Table IV indicate the accumulation of an inhibitor, since each successive addition of citrylCoA is hydrolyzed more slowly than the preceding one.

Further evidence which shows that the site that catalyzes the condensation reaction is probably the same as the site which catalyzes the hydrolysis of citrylCoA. The crystalline condensing enzymes from moth muscle and pigeon breast muscle $^{5,6}$ also catalyzed the hydrolysis of citryl-CoA. The ratios of the rate of condensing enzyme reaction to the rate of citryl-CoA hydrolysis for the three enzymes are very similar. Condensing enzyme is inactivated under mild acetylation

TABLE IV

CUMULATIVE INHIBITORY EFFECT OF CITRYL-COA ON ITS HYDROLYSIS

Cuvettes contained o.I 75 unit of condensing enzyme, $200 \mu$ moles Tris $-\mathrm{HCl}$ and o.I $\mu$ mole DTNB in a total volume of $\mathrm{I} \mathrm{ml}$. In each case the reaction proceeded to completion before the next addition of substrate.

\begin{tabular}{lc} 
Citryl.CoA & $\begin{array}{c}\text { Time for } \\
\text { o.o5o } \Delta A \\
\text { at } 412 \mathrm{m \mu} \\
(\mathrm{sec})\end{array}$ \\
\hline First addition, 6.0 m $\mu$ moles & 35 \\
Second addition, 6.0 m $\mu$ moles & 53 \\
Third addition, 6.0 m $\mu$ moles & 85 \\
Fourth addition, 6.0 m $\mu$ moles & 155 \\
\hline
\end{tabular}


conditions. When 3-4 acetyl groups are introduced per mole of enzyme the condensation activity is reduced $70 \%$. Inactivation of condensing enzyme by acetylation results in a parallel loss of condensing enzyme activity against acetyl-CoA and oxaloacetate and against citryl-CoA (Table V).

In a recent report from this laboratory we have shown that citryl-CoA is cleaved by the citrate cleavage enzyme ${ }^{9}$. The rate of cleavage of citryl-CoA to acetyl-CoA and oxaloacetate was slightly greater than the rate of the overall reaction from citrate, ATP, and CoA. In the cleavage of citryl-CoA by cleavage enzyme no evidence was obtained for an inhibition by the unnatural diastereomer.

The results indicate therefore that citryl-CoA can serve as a substrate for both

\section{TARLE V}

LOSS OF CONDENSING ENZYME ACTIVITY AND CITRYL-COA HYDROLYSIS ACTIVITY BY ACETYLATION OF ENZYME

\begin{tabular}{ccc}
$\begin{array}{c}\text { Acctic } \\
\text { anhydride } \\
\text { addition } \\
(\mu l)\end{array}$ & $\begin{array}{c}\text { Condensing } \\
\text { enzyme } \\
\text { (\% activity) }\end{array}$ & $\begin{array}{c}\text { Citryl-Co.1 } \\
\text { hydrolysis } \\
\text { (\% activity })\end{array}$ \\
\hline 0 & 100 & 100 \\
30 & 35 & 27 \\
40 & $2 \mathrm{I}$ & 13 \\
50 & 9 & 2.0 \\
60 & 1.5 & 1.5 \\
70 & 0.0 & 0.1 \\
\hline
\end{tabular}

* Diluted 1:25 in tetrahydrofuran.

the citrate cleavage and citrate condensing enzymes. There is no direct evidence, however, that indicates it is an intermediate in the catalyzed reactions.

I would like to thank Mrs. L. Gonen and Mrs. B. Torp for technical assistance. This work was supported in part by a grant from the U.S. Public Health Service ( $\mathrm{H}_{5328)}$.

Department of Biological Chemistry,

Paul A. SRERE*

The University of Michigan,

Ann Arbor, Mich. (U.S.A.)

${ }^{1}$ G. W. Kosicki, Ph. D. Dissertation, The University of Michigan.

2 P. A. Srere and G. W. Kosicki, Abstr. of the 5th Intern. Congr. Biochem., Moscow, ig6I, Pergamon Press, Oxford, 1961. p. 125.

3 H. Eggerer and U. Remberger, Biochem. $Z$., 337 (ig63) 202.

4 G. EllmaN, Arch. Biochem. Biophys., 82 (1959) 70

5 P. A. SRere and H. Brazil, Federation Proc., 2 I (r962) 253.

- P. A. SRere, H. Brazir and L. Gonen, Acta Chem. Scand., 7 (1963) 5129.

7 P. A. SRERE, J. Biol. Chem., 236 (196I) 50 .

8 J. G. Moffatt and H. G. Khorana, J. Am. Chem. Soc., 83 (1961) 663.

9 P. A. Srere, Biochim. Biophys. Acta, 73 (1963) 523.

Received August 5th, 1963

* Present addres: University of California, Bio-Medical Division, Lawrence Radiation Laboratory, Livermore, Calif. (U.S.A.) 